\title{
IMPLEMENTASI KURIKULUM 2013 DI KELAS II SD MUHAMMADIYAH 4 TERPADU SAMARINDA
}

\author{
Nani Astutiningsih \\ Program Studi Pendidikan Guru Sekolah Dasar Universitas Mulawarman Samarinda \\ astutiningsihn119@gmail.com
}

\begin{abstract}
Abstrak
Penelitian ini bertujuan untuk mendeskripsikan implementasi pembelajaran Kurikulum 2013, mendeskripsikan evaluasi pelaksanaan Kurikulum 2013, mendeskripsikan hambatan-hambatan yang ditemui guru dalam melaksanakan implementasi Kurikulum 2013, dan mendeskripsikan solusi yang dilakukan guru untuk mengatasi hambatan dalam pelaksanaan implementasi Kurikulum 2013 kelas II SD Muhammadiyah 4 Terpadu Samarinda. Metode penelitian yang digunakan penelitian kualitatif yang menghasilkan data deskriptif. Instrumen pengumpulan data yang digunakan pada penelitian kualitatif ini adalah berupa kata-kata tertulis atau lisan dari orang-orang dan perilaku yang dapat diamati, menggunakan metode wawancara, observasi partisipatif, dokumentasi dan catatan lapangan. Tehnik analisis data yaitu analisis interaktif. Hasil penelitian menunjukkan bahwa aspek-aspek Implementasi meliputi perencanaan, proses pembelajaran di sekolah, dan kegiatan monitoring dan evaluasi. Evaluasi pelaksanaan Kurikulum 2013 di SD Muhammadiyah Samarinda perlu diawali dengan pemenuhan Standar Nasional Pendidikan. Pembahasan: Hambatanhambatan yang menjadi kendala guru kelas II SD Muhammadiyah 4 Terpadu Samarinda pada pelaksanaan Kurikulum 2013 adalah pada penilaian autentik yang terdiri dari 4 aspek yaitu aspek sosial, aspek spiritual, aspek pengetahuan dan aspek keterampilan. Solusi dalam menghadapi hambatan dalam Implementasi Kurikulum 2013 yaitu (1) mengikutkan guru-guru dalam workshop-workshop tentang Kurikulum 2013, (2) melengkapi sarana/prasaran, (3) mengadakan evaluasi setiap 1 semester, (4) membentuk tim khusus pengembang Kurikulum 2013, (5) rutin melakukan supervisi guru. Kesimpulan: Pelaksanaan Kurikulum 2013 kelas II SD Muhammadiyah 4 Terpadu Samarinda sudah berlangsung baik.
\end{abstract}

Kata Kunci: Implementasi, Evaluasi, Hambatan pelaksanaan, Solusi hambatan Kurikulum 2013.

\begin{abstract}
This study aims to describe the implementation of 2013 Curriculum learning, describe the evaluation of the implementation of 2013 Curriculum, describe the obstacles encountered by teachers in implementing the 2013 Curriculum, and describe the solutions made by teachers to overcome obstacles in the implementation of the 2013 second curriculum implementation of Muhammadiyah 4 Elementary School Samarinda. The research method used is qualitative research that produces descriptive data. Data collection instruments used in this qualitative study were in the form of written or spoken words from people and observable behavior, using interview methods, participatory observation, documentation and field notes. Data analysis technique is interactive analysis. The results showed that the aspects of Implementation included planning, learning processes in schools, and monitoring and evaluation activities. Evaluation of the implementation of the 2013 curriculum at SD Muhammadiyah Samarinda needs to begin with the fulfillment of the National Education Standards. Discussion: The obstacles that become obstacles of class II teachers of SD Muhammadiyah 4 Integrated Samarinda in the implementation of the 2013 Curriculum are on authentic assessment which consists of 4 aspects namely social aspects, spiritual aspects, aspects of knowledge and aspects of skills. Solutions to face obstacles in the Implementation of the 2013 Curriculum are (1) involving teachers in workshops on the 2013 Curriculum, (2) completing facilities / projects, (3) conducting an evaluation every 1 semester, (4) forming a special team to develop the 2013 Curriculum, (5) routinely conducts teacher supervision. Conclusion: The implementation of 2013 Class II Curriculum Muhammadiyah 4 Integrated SD Samarinda has been going well.
\end{abstract}

Keywords: Implementation, Evaluation, Implementation barriers, Solution to 2013 Curriculum constraints

\section{PENDAHULUAN}

Tujuan pendidikan di sekolah adalah untuk menciptakan sekolah dengan suasana pembelajaran yang demokratis dan menyenangkan, dibutuhkan perubahan yang cukup mendasar dalam sistem pendidikan. Perubahan sistem pendidikan berkaitan dengan kurikulum, karena kurikulum merupakan suatu perangkat yang penting yang digunakan sebagai pedoman kegiatan pembelajaran di sekolah. Hal tersebut sesuai dengan pengertian kurikulum menurut Peraturan Pemerintah Republik Indonesia Nomor 19 Tahun 2005 tentang Standar
Nasional yang menuliskan bahwa kurikulum adalah seperangkat rencana dan pengaturan mengenai tujuan, isi, dan bahan pelajaran serta cara yang digunakan sebagai pedoman penyelenggaraan kegiatan pembelajaran untuk mencapai tujuan tertentu.

Kurikulum 2013 adalah kurikulum berbasis kompetensi, pengembangan kurikulum 2013 diarahkan pada pencapaian kompetensi yang dirumuskan dari Standar Kelulusan (SKL). Penyusunan Kurikulum 2013 dimulai dengan menetapkan standar kompetensi lulusan berdasarkan kesiapan siswa dan tujuan pendidikan 


\section{Nani Astutiningsih. Jurnal Pendas Mahakam. Vol 5 (2). 140-155 Desember 2020}

nasional. Kurikulum 2013 ditetapkan menjadi alat penyelenggara pendidikan pertama kali pada tahun ajaran 2013/2014.

Kurikulum 2013 dikembangkan dalam rangka merespon salah satu tantangan eksternal, yakni terkait dengan rendahnya mutu pendidikan dikanca internasional terutama di negara ASEAN. Pembelajaran tematik membuat peserta didik terlibat secara aktif dalam proses pembelajaran dan pemberdayaan dalam memecahkan masalah serta tumbuhnya kreatifitas sesuai kebutuhan mereka. Oleh karena itu, hendaknya para guru meningkatkan keterampilan berifikir kritisnya sehingga siswa dapat menyelesaikan masalah dengan cara yang semestinya seperti yang tertuang dalam sikap kritis (Fitriadi, 2016). Hal yang memberikan perbedaan mencolok antara Kurikulum 2013 dengan kurikulum sebelumnya adalah penekanan ranah pembelajaran. Kurikulum 2013 menekankan pada proses pendidikan yang holistik sehingga menyentuh pada cakupan yang lebih luas yaitu ranah kognitif, afektif, dan psikomotor.

Awal penerapan Kurikulum 2013 dalam kegiatan belajar mengajar membutuhkan berbagai macam penyesuaian. Untuk itu guru selalu berusaha semaksimal mungkin mengikuti petunjuk yang diperoleh dari sosialisasi Kurikulum 2013 yang didapatkan. Kepala sekolah menyatakan bahwa terdapat beberapa hambatan dalam tahap penyesuaian dan penerapan Kurikulum 2013, yaitu, beberapa guru kelas sasaran implementasi Kurikulum 2013 belum sepenuhnya mendalami konsep dan pengembangan Kurikulum 2013. Hal ini dikarenakan sosialisasi yang didapatkan belum sepenuhnya dipelajari dalam waktu singkat. Seorang guru harus menyadari apa saja yang dikaitkan dengan yang ada dan situasi dilingkungan kelasnya. Menurut penelitian, menyatakan bahwa peran guru dalam pembelajaran masih dominan, sehingga aktifitas belajar masih terfokus pada apa yang diinstruksikan guru (teacher centered). Guru harus melakukan apa saja yang dapat dilakukan untuk memperbanyak jumlah unconditioned stimulus yang menyenangkan dan berusaha untuk mengurangi unconditioned stimulus yang tidak menyenangkan.

Pada tahap perencanaan pembelajaran dibutuhkan rencana pelaksanaan pembelajaran (RPP) secara matang. Selain itu, dalam RPP tertulis 4 kompetensi inti yang memuat kegiatankegiatan seperti, mengamati, menanya, mencoba, mengasosiasikan dan mengkomunikasikan. Kegiatan tersebut merupakan konsep baru yang terdapat dalam Kurikulum 2013, yang merupakan proses kegiatan pembelajaran dalam pendekatan saintifik.

Dalam pelaksanaan pembelajaran, guru sudah memberikan pembelajaran berbasis tematik yang menggunakan sumber belajar utama berupa buku siswa dari Kementerian Pendidikan dan Kebudayaan Republik Indonesia dan didukung buku Bupena terbitan Erlangga. Buku siswa yang digunakan merupakan edisi revisi tahun 2017 yang merupakan buku penyempurnaan dari tahun sebelumnya. Kurikulum 2013 berisi satu tema dan isi materinya berasal dari integrasi 4 mata pelajaran, sedangkan pada kurikulum sebelumnya hanya memuat satu mata pelajaran. Pada saat pelaksanaan pembelajaran, guru mengalami hambatan dengan alokasi waktu yang harus dibagi dengan mata pelajaran lain diluar pembelajaran tematik. Untuk itu, perlu adanya tinjauan ulang untuk alokasi waktu yang tepat, khususnya untuk kelas yang menerapkan Kurikulum 2013. Hal ini merupakan salah satu hambatan yang dialami oleh guru karena harus menyesuaikan kembali jadwal pelajaran setiap harinya, sehingga pembelajaran berjalan kurang sesuai dengan tema-tema yang seharusnya diajarkan. Selain itu, beberapa guru sulit membuat siswa aktif dikelas dan sulit membimbing siswa untuk mencari sendiri pengetahuan yang dibutuhkan, dikarenakan siswa terbiasa menjadikan guru sebagai satu-satunya pusat sumber belajar.

Menurut hasil penelitian Fithry(2013), Kurikulum 2013 sebenarnya tidak semuanya merupakan hal-hal yang baru. Artinya komponenkomponen yang ada pada Kurikulum Tingkat Satuan Pelajaran(KTSP) sebagian masih terdapat pada Kurikulum 2013. Menurut hasil penelitian Sunaryo (2009), dalam pelaksanaan pembelajaran, guru dituntut memiliki berbagai keterampilan atau kreatifitas mengajar, strategi belajar mengajar yang tepat, dan kemampuan melaksanakan evaluasi yang baik. Dengan wawasan yang luas, guru mampu memperhitungkan berbagai kemungkinan yang terjadi, tujuannya adalah agar guru dapat memahami bahwa dalam melaksanakan fungsi dan perannya sebagai fasilitator pendidikan, guru diharapkan mempunyai kemampuan dan kreatifitas dalam 
menjalankan kegiatan mengajar sebagai transforming science pada siswa sebagai penerima dan pengembang ilmu yang telah diberikan oleh guru selama kegiatan pengajaran berlangsung di dalam kelas.

Tujuan dari perubahan kurikulum tersebut bertujuan untuk meningkatkan karakteristik siswa yang dipandang semakin banyaknya pengaruhpengaruh global yang muncul sehingga memungkinkan akan mempengaruhi karakter siswa. Penilaian pembelajaran dalam Kurikulum 2013 berorientasi pada fokus penilaian pembelajaran Kurikulum 2013 mengalami perubahan dari kurikulum sebelumnya. Fokus penilaian kurikulum sebelumnya adalah pada penilaian keberhasilan kompetensi pengetahuan siswa, sedangkan kurikulum 2013 adalah keberhasilan pembentukan sikap dan keterampilan lebih diutamakan daripada pengetahuan. Berdasarkan konsep penilaian pembelajaran Kurikulum 2013, SD Muhammadiyah 4 Samarinda telah menggunakan penilaian autentik dalam penilaian pembelajarannya. Hambatannya adalah guru-guru membutuhkan waktu yang lama untuk memasukkan nilai-nilai perolehan siswa dari berbagai macam penilaian autentik (penilaian portofolio, penilaian unjuk kerja, penilaian sikap) ke dalam daftar nilai. Penilaian harus selesai dalam satu hari tetapi sangat sulit dilakukan, selain karena waktu mengajar yang masih perlu penyesuaian, ditambah lagi penilaian autentik yang cukup menyita waktu.

Implementasi Kurikulum 2013 mulai diterapkan beberapa sekolah yang dianggap memenuhi kriteria yang ditentukan Kementrian Pendidikan dan Kebudayaan Republik Indonesia. SD Muhammadiyah 4 Terpadu Samarinda adalah salah satu sekolah yang ditunjuk sebagai pilot project pelaksanaan Kurikulum 2013. Pada tahun pertama sekolah ini menerapkan Kurikulum 2013 dikelas I dan IV yaitu tahun 2013. Pada tahun 2019 ini seluruh kelas mulai kelas I sampai kelas VI sudah melaksanakan pembelajaran Kurikulum 2013. Dalam wawancara pertama kalinya dengan wali kelas II, beliau menuturkan masih mengalami kesulitan, yaitu perencanaan pembelajaran tematik yang memakan waktu dan tenaga yang lebih banyak, mulai penyusunan matriks tematik, proses, silabus dan RPP sekaligus dibuat dalam satu semester. Selain itu pula, tidak berurutannya materi yang diajarkan dan persiapan media pembelajaran yang perlu disesuaikan dengan tema. Ada pula yang berpendapat, masih terjadinya selisih pendapat para guru tentang pengertian, maksud dan tujuan Pembelajaran Tematik, sehingga menimbulkan kebingungan dan merasa berat untuk menerapkan pembelajaran. Para siswa merasa kebingungan ketika belajar selalu berpindah dari muatan pelajaran satu ke muatan pelajaran lain tanpa ada jeda dan ganti buku, sehingga buku tulis anakanak tak beraturan. Sehubungan dengan hasil wawancara dan observasi dengan beberapa guru diperlukan penelitian tentang implementasi Kurikulum 2013 ini. Bagaimana kesiapan sekolah dan para guru serta para siswa dalam melaksanakan Kurikulum 2013 ini.

Pada tahap persiapan, belum semua guru terampil mengoperasikan IT sehingga menghambat kelancaran dalam pelaksanaan tugas seperti pembuataan RPP, pengolahan nilai, menggunakan media pembelajaran multimedia, dan lainnya. Sebagian materi pada Buku Siswa kurang urut tingkat kesulitannya karena disusun berdasarkan tema. Materi pembelajaran pada buku siswa maupun buku guru sangat minim sehingga harus menggunakan buku pendamping yang relevan. Guru juga mengalami kendala dalam pelaksanaan, di antaranya siswa kelas I masih belum bisa membaca dan menulis dengan lancar. Kendala lain yaitu pelaksanaan pembelajaran tidak dapat tuntas dalam satu kali pertemuan atau satu hari karena banyaknya kegiatan yang harus dilakukan guru dan siswa. Dalam pembelajaran guru melakukan penilaian autentik untuk setiap aspek, dan siswa menyelesaikan kegiatan pembelajaran yang padat.

$$
\text { Guru juga kesulitan dalam }
$$
mengakomodasikan pendekatan saintifik dengan 5 langkah (mengamati, menanya, mencoba, menalar, mengkomunikasikan) pada kegiatan pembelajaran. Kesulitan ini ditambah ketika anak kurang aktif, padahal tuntutan dengan pendekatan saintifik ini, siswa harus aktif. Untuk siswa kelas IV, pada awalnya masih kebingungan dengan konsep pembelajaran tematik terpadu karena terbiasa dengan pendekatan mata pelajaran. Pada tema-tema tertentu sering tidak ada keterkaitan atau kalaupun ada keterkaitan terkesan dipaksakan. Kendala dalam tahap evaluasi/penilaian yang dihadapi guru antara lain: sistem penilaian autentik belum bisa dilakukan secara maksimal oleh guru mengingat banyaknya jumlah siswa dan banyaknya unsur penilaian. 
Termasuk didalamnya dalam men-setting daftar nilai, buku laporan hasil belajar (rapot). Guru belum memahami pedoman penilaian sehingga kesulitan membuat soal UTS/UAS dalam mengungkap aspek pengetahuan apakah mengacu kepada tema atau mata pelajaran.

Orang tua/ wali murid juga mengalami kendala dalam membimbing belajar di rumah karena masih bingung dengan konsep pembelajaran tematik terpadu. Kurikulum 2013 menuntut orang tua untuk proaktif dalam membimbing dan mempersiapan alat/bahan untuk kegiatan sekolah. Hal ini menjadi masalah bagi orang tua yang terlalu sibuk. Implementasi kurikulum 2013 juga dilihat dari berbagai aspek seperti kondisi siswa, kondisi guru, kondisi sarana prasarana, penyusunan perencanaan pembelajaran, pelaksanaan pembelajaran, dan penilaian pembelajaran. Oleh karenanya akan dilakukan evaluasi pelaksanaan Kurikulum 2013.

Lestari (2012) dalam artikelnya dikatakan bahwa kendala penerapan pembelajaran Tematik yang dialami oleh guru yaitu belum memahami dengan baik tentang pembelajaran tematik, sehingga kemampuan untuk menerapkan model pembelajaran tematik terbatas. Pendapat lain menurut Karli, Hilda (2012) mengatakan bahwa kendala Pembelajaran Tematik adalah sebagai berikut: (a) Perencanaan pembelajaran tematik yang memakan waktu dan tenaga yang lebih banyak mulai dari penyusunan matriks tematik, jaring laba-laba, program semester, silabus dan RPP sekaligus dibuat dalam 1 semester; (b) Tidak berurutan materi yang diajarkan kecuali Matematika dalam 1 semester; dan (c) Menyiapkan media perlu disesuaikan dengan pemilihan tema.

Berdasarkan uraian tentang pelaksanaan Kurikulum 2013 dan penyelenggaraan dalam kegiatan belajar mengajar di SD Muhammadiyah 4 Terpadu Samarinda serta berbagai permasalahan yang ada, maka peneliti tertarik untuk mengetahui lebih lanjut mengenai bagaimana implementasi Kurikulum 2013 di SD Muhammadiyah 4 Samarinda yang berkaitan dengan upaya guru kelas II dalam melaksanakan kegiatan perencanaan, pelaksanaan pembelajaran, dan penilaian pembelajaran serta hambatan lainnya dalam proses implementasi kurikulum tersebut dan upaya untuk mengatasi berbagai hambatan tersebut.

\section{METODE PENELITIAN}

Pendekatan yang digunakan dalam penelitian ini adalah penelitian kualitatif dengan prosedur penelitian yang menghasilkan data deskriptif berupa kata-kata tertulis atau lisan dari orang-orang dan perilaku yang dapat diamati. Penelitian diarahkan pada latar dan individu tersebut secara holistik (utuh), tidak boleh mengisolasikan individu atau organisasi ke dalam variabel atau hipotesis, tetapi perlu memandangnya sebagai bagian dari sesuatu kebutuhan. Penelitian kualitatif digunakan dalam penelitian ini, karena pada umumnya permasalahannya belum jelas, holistik, dinamis dan penuh makna sehingga tidak mungkin data pada situasi sosial tersebut diperoleh dengan metode penelitian kuantitatif dengan instrumen seperti test, kuesioner, pedoman wawancara. Metode yang digunakan untuk mengkaji mengenai implementasi Kurikulum 2013 adalah studi kasus, yaitu penelitian yang mendalam tentang individu, satu kelompok, satu organisasi atau satu program dalam waktu tertentu. Tujuannya untuk memperoleh deskripsi yang utuh dan mendalam dari sebuah entitas dengan prosedur perolehan data dari wawancara, observasi dan arsip.

Penelitian ini mengambil tempat atau lokasi di SD Muhammadiyah 4 Terpadu Samarinda, beralamat di Jalan Wahid Hasyim 2 Gang Ahim 1, Sempaja Timur, Samarinda Utara Kota Samarinda. Adapun setting penelitian yang diteliti adalah seluruh aktivitas yang terkait dengan Implementasi Kurikulum 2013 khususnya yang berkaitan dengan upaya-upaya mewujudkan komponen-komponen implementasi kurikulum 2013, meliputi : pengembangan rencana pembelajaran, proses pembelajaran dan evaluasi, sebagai upaya meningkatkan kualitas pembelajaran. Penelitian ini dilakukan pada bulan Januari - Maret 2020.

Data dalam penelitian ini diperoleh melalui kegiatan pengamatan, catatan lapangan dan dokumentasi terhadap aktifitas siswa dan guru kelas II SD Muhammadiyah 4 Terpadu dalam pengimplementasian Kurikulum 2013 pada kegiatan belajar mengajar di kelas. Sumber data yang digunakan adalah warga sekolah yang meliputi; Kepala sekolah, wakil kepala sekolah dan 2 orang guru. 
HASIL PENELITIAN

Implementasi pembelajaran Kurikulum 2013 kelas II SD Muhammadiyah 4 Terpadu Samarinda

a. Pengetahuan walikelas II mengenai Kurikulum 2013

Hasil wawancara mendalam serta observasi atau pengamatan dapat diketahui bahwa pengertian walikelas II mengenai Kurikulum 2013 SD Muhammadiyah 4 Terpadu. Berikut hasil wawancara dengan walikelas II. Ibu Norsidah, selaku walikelas II-1 menyatakan sebagai berikut: "Kurikulum 2013 adalah kurikulum yang di canangkan oleh pemerintah di tahun 2013 yang merupakan penyempurna dari kurikulum sebelumnya. Kurikulum 2013 merupakan pengembangan dari kurikulum KTSP, hanya dalam proses pembelajaran menggunakan pendekatan santifik dan menggunakan penilaian autentik. Pada prinsipnya pola pembelajarannya dari pasif menjadi pola pembelajaran aktif mencari, pembelajaran dengan kreatif dan inovatif agar siswa lebih memiliki pengalaman belajar yang menyenangkan." Beliau tambahkan pula "Kurikulum 2013 merupakan pengembangan dari kurikulum sebelumnya yaitu KTSP yang tidak jauh beda hanya saja kurikulum 2013 menggunakan pendekatan saintifik dan menggunakan penilaian autentik. Pada prinsipnya dalam kurikulum 2013 adalah pola pembelajaran yang berpusat pada guru menjadi pembelajaran berpusat pada siswa. Menurut Ibu Lutfiatul Khoiroh, selaku walikelas II-4, menyatakan sebagai berikut: "Kurikulum 2013 adalah sebuah kurikulum yang terintegrasi, maksud dari integrasi ini adalah sebuah kurikulum yang mengintegrasikan skill, theme, concepts, and topic baik dalam bentuk within sigle disciplines, acrous several disciplines and within and acrous learners. Dengan kata lain bahwa kurikulum 2013 ialah kurikulum yang terpadu sebagai suatu konsep dapat dikatakan sebagai sebuah sistem atau pendekatan pembelajaran yang melibatkan beberapa disiplin ilmu untuk memberikan pengalaman yang bermakna dan luas kepada siswa." Beliau tambahkan pula, "Kurikulum 2013 merupakan kurikulum pengembangan dari KTSP dimana ada perbedaan di dalam proses pembelajaran menggunakan pendekatan saintifik dan penilaian autentik. Prinsip dalam kurikulum 2013 adalah siswa mempunyai kompetensi, mengetahui dan tidak hanya sekedar menghafal saja, tetapi siswa benar-benar mampu memahami dan mengaplikasikannya dalam kehidupan seharihari dan diharapkan siswa memiliki karakter atau budi pekerti yang dalam bahasa agama yaitu akhlakhul karimah." Zaenal Arifin, selaku Wakil Kepala Sekolah bagian Kurikulum menyatakan: "Kurikulum 2013 merupakan pengembangan KTSP dengan menggunakan pendekatan saintifik dan penilaian autentik, pada prinsipnya dalam kurikulum 2013 sekolah merupakan bagian dari masyarakat yang memberikan pengalaman belajar terencana dimana siswa menerapkan apa yang dipelajari di sekolah di masyarakat dan memanfaatkannya sebagai sumber belajar".

Kurikulum 2013 merupakan kurikulum baru yang dicanangkan oleh pemerintah pada tanggal 25 Juli 2013 dan berlaku di beberapa sekolah yang mulai diterapkan tahun pelajaran 2013/2014. Pada prinsipnya pembelajaran dengan menggunakan pendekatan saintifk yang melalui beberapa langkah yaitu, mengamati, menanya, mengumpulkan informasi, mengasosiasi dan mengkomunikasikan serta menerapkan penilaian secara autentik.

Perbedaan kurikulum 2013 dengan KTSP guru-guru menyatakan bahwa : Menurut Ibu Norsidah : "garis besarnya kurikulum 2013 dengan kurikulum sebelumnya yaitu KTSP sama, yang membedakan adalah Silabus sudah dari pusat dan ada panduan untuk membuat RPP. Menggunakan pendekatan saintifik dan penilaian autentik, silabus merupakan rencana pembelajaran pada mata pelajaran atau tema tertentu yang mencakup kompetensi inti, kompetensi dasar, materi, kegiatan pembeajaran, penilaian, alokasi waktu dan sumber belajar, "Sedangkan Rencana Pelaksanaan Pembelajaran (RPP) menurut saya yaitu Rencana Pelaksanaan Pembelajaran yang isinya meliputi rencana saya pada waktu akan memulai pembelajaran seperti jenis-jenis jenjang pendidikan selanjutnya berisi mata pelajaran, alokasi waktu, kemudian kompetensi dasar apa yang mau dicapai, selanjutnya dijabarkan langkah-langkah saya pada waktu mengajar dan melakukan penilaian dari proses awal sampai akhir, serta apa saja yang perlu dipersiapkan dan seterusnya." Menurut Ibu Lufiatul Khoiroh, selaku walikelas II-4 menyatakan sebagai berikut: "Kurikulum 2013 merupakan kurikulum pengembangan dari KTSP dimana ada perbedaan di dalam proses pembelajaran menggunakan pendekatan saintifik dan penilaian autentik. 
Prinsip dalam kurikulum 2013 adalah siswa mempunyai kompetensi, mengetahui dan tidak hanya sekedar menghafal siswa benar-benar mampu memahami dan mengaplikasikannya dalam kehidupan sehari-hari dan diharapkan siswa memiliki karakter atau budi pekerti yang dalam bahasa agama yaitu akhlakhul karimah." Beliau tambahkan pula : "Dalam kurikulum 2013 silabus yang merupakan panduan dalam pembuatan Rencana Pelaksanaan pembelajaran (RPP) sudah ada yang dibuat oleh pemerintah kita tingggal menuangkan dalam RPP”.

\section{b. Persiapan pembelajaran}

Berdasarkan hasil wawancara, observasi atau pengamatan serta studi dokumentasi yang dilakukan mulai tanggal 7 januari 2020 dapat diketahui persiapan pembelajaran yang dilakukan oleh walikelas II. Secara garis besarnya meliputi sebagai berikut:

\section{1). Pengembangan program}

Langkah pertama persiapan pembelajaran yang dilakukan oleh walikelas II adalah melakukan pengembangan program. Dalam kurikulum 2013 pengembangan program mencakup program tahunan, program semester, program mingguan dan harian, program pengayaan dan remedial serta program bimbingan dan konseling. Program tahunan merupakan program setiap mata pelajaran untuk jangka waktu satu tahun dalam rangka mengefektifkan program pembelajaran. Program ini dipersiapkan dan dikembangkan oleh guru sebelum tahun ajaran baru, karena merupakan pedoman bagi pengembangan program-program berikutnya yaitu program semester, program mingguan dan harian, dan program harian atau program pembelajaran setiap kompetensi dasar. Program tahunan yang disusun oleh walikelas II diantaranya memuat standar kompetensi dan kompetensi dasar yang harus dikuasai siswa setelah mempelajari pokok bahasan tertentu, alokasi waktu serta keterangan.

Program semester berisikan garis-garis besar mengenai hal-hal yang hendak dilaksanakan dan dicapai dalam semester tersebut. Program semester merupakan penjabaran dari program tahunan. Program semester yang disusun oleh guru walikelas II berisikan tentang bulan, pokok bahasan yang hendak disampaikan, alokasi waktu serta keterangan-keterangan. Program mingguan dan harian merupakan penjabaran dari program semester, dari program ini dapat teridentifikasi siswa-siswa yang mengalami kesulitan belajar akan dilayani melalui kegiatan remedial, sedangkan untuk siswa yang cemerlang akan dilayani melalui kegiatan pengayaan agar siswa tersebut tetap mempertahankan kecepatan belajarnya. Ibu Lutfiatul Khoiroh, M.Pd, selaku guru kelas II-4 mengungkapkan bahwa : "Saya melaksanakan program remedi dilakukan untuk siswa yang nilainya masih dibawah standar nilai ketuntasan, siswa tersebut diberi kesempatan untuk menuntaskan kompetensi-kompetensi dasar yang belum tuntas. Sedangkan program pengayaan diberlakukan bagi siswa yang nilainya diatas nilai standar ketuntasan, program pengayaan tersebut seperti pemberian tugas-tugas atau dalam bentuk soal-soal yang bisa dikerjakan secara individu maupun kelompok ". Hal tersebut diperkuat dengan pernyataan Ibu Norsidah selaku guru walikelas II-1 mengemukakan sebagai berikut : " setiap ada siswa yang nilainya masih kurang, siswa akan dipanggil oleh pihak sekolah untuk diberi pengarahan agar mengikuti program remedial".

Program pengembangan diri di SD Muhammadiyah 4 Terpadu sebagian besar melalui kegiatan ekstrakurikuler maupun bimbingan konseling, hal ini berdasarkan pernyataan Bapak Zaenal Arifin, selaku wakil kepala sekolah SD Muhammadiyah 4 Terpadu sebagai berikut : "Setiap ada siswa yang nilainya kurang, siswa akan dipanggil oleh pihak sekolah untuk diberi pengarahan agar mengikuti program remedial. Salah satu kegiatan pengembangan diri dilakukan melalui kegiatan extrakurikuler."

2). Penyusunan Persiapan Mengajar

Sebagai persiapan mengajar guru kelas II SD Muhammadiyah 4 Terpadu mencermati silabus dan Rencana Pelaksanaan Pembelajaran (RPP). Silabus adalah rencana pembelajaran tema tertentu. Silabus yang disusun, mencakup Kompetensi Inti, kompetensi dasar, materi pembelajaran, kegiatan pembelajaran, indikator, penilaian, alokasi waktu, dan sumber belajar yang dikembangkan oleh setiap satuan pendidikan.

Hasil wawancara dengan guru kelas II di SD Muhammadiyah 4 Terpadu mengenai penyusunan silabus Ibu Lutfiatul Khoiroh, selaku guru kelas II-4 SD Muhammadiyah 4 Terpadu mengemukakan : "Silabus merupakan rencana pembelajaran pada mata pelajaran atau tema tertentu yang didalamnya mencakup Kompetensi Inti, Kompetensi Dasar, Materi Pembelajaran, 
Kegiatan Pembelajarannya, penilaian, alokasi waktu dan sumber belajar. Dalam Kurikulum 2013 silabus sudah disiapkan dari pemerintah guru tinggal mengembangkan dalam Rencana Pelaksanaan Pembelajaran, namun dalam penerapannya di perlukan pembahasan agar mendapatkan konsep yang sesuai dengan harapan dan tujuan pembelajaran, di SD Muhammadiyah 4 Terpadu dalam hal ini menerapkan supervisi kepada guru-guru dalam menerapkan rencana pembelajaran".

Menurut Ibu Lutfiatul Khoiroh, selaku guru kelas II-4 SD Muhammadiyah 4 Terpadu mengemukakan sebagai berikut : " Berkaitan silabus, sekarang sudah ditentukan dari pusat, guru tinggal mengembangkan dan menuangkan dalam Rencana Pelaksanaan Pembelajaran. Uraian serupa dikemukakan oleh Ibu Norsidah, guru kelas II-1 SD Muhammadiyah 4 Terpadu sebagai berikut : "Berkaitan dengan silabus, sekarang sudah ada dari pusat, selanjutnya dikembangkan sendiri. Silabus tersebut dijadikan acuan atau pedoman dalam membuat Rencana Pelaksanaan Pembelajaran (RPP). Di dalam silabus dijelaskan mengenai Kompetensi Inti, Kompetensi Dasar, Media Pembelajaran, Metode Pembelajaran yang selanjutnya dijabarkan dalam Rencana Pelaksanaan Pembelajaran (RPP).”

Pernyataan guru-guru tersebut diperkuat dengan pernyataan Wakil Kepala Sekolah SD Muhammadiyah 4 Terpadu, Bapak Zaenal Arifin, sebagai berikut: "Dalam Kurikulum 2013 silabus yang merupakan rencana pembelajaran pada mata pelajaran atau tema sudah ada panduannya dari pemerintah, jadi guru tinggal menerapkan dan menjabarkan dalam bentuk Rencana Pelaksanaan Pembelajaran (RPP).”

Penerapan atau penjabaran silabus ke dalam RPP oleh guru kelas II SD Muhammadiyah 4 Terpadu tidak mengalami hambatan yang berarti. Hal ini berdasarkan pernyataan Ibu Lutfiatul Khoiroh, selaku guru kelas II-4 SD Muhammadiyah 4 Terpadu sebagai berikut : "Dalam penelaahan dan penjabaran silabus dalam RPP, saya tidak mengalami hambatan yang berarti karena dalam hal ini kami mengadakan penelaahan bersama dengan guru-guru kelas II di SD Muhammadiyah 4 Terpadu, sehingga akan memudahkan kami dalam menjabarkan silabus ke RPP." Hal tersebut diperkuat dengan pernyataan Ibu Norsidah, selaku guru kelas II-1 SD Muhammadiyah 4 Terpadu sebagai berikut : “
Dalam penelaahan dan penjabaran silabus ke dalam RPP saya tidak mengalami hambatan, karena sudah di bahas bersama guru kelas II lainnya". (CL P W 01 14.01.20 ). Selanjutnya mengenai manfaat dari silabus, berikut hasil wawancara dengan Ibu Lutfiatul Khoiroh, selaku guru kelas II SD Muhammadiyah 4 Terpadu sebagai berikut : "Manfaat dari silabus adalah sebagai pedoman dalam pengembangan pembelajaran lebih lanjut, seperti pembuatan Rencana Pelaksanaan Pembelajaran (RPP), pengelolaan kegiatan pembelajaran dan pengembangan sistem nilai."

Persiapan pembelajaran berikutnya yang disusun oleh guru kelas II SD Muhammadiyah 4 Terpadu berupa Rencana Pelaksanaan Pembelajaran (RPP), RPP merupakan perencanaan jangka pendek untuk memperkirakan atau memproyeksikan apa yang akan dilakukan dalam pembelajaran dan adakah hambatan dalam menyusun Rencana Pelaksanaan Pembelajaran. Rencana Pelaksanaan Pembelajaran ( RPP) berisi tentang : alokasi waktu, kompetensi inti, kompetensi dasar, indikator, tujuan pembelajaran, materi pembelajaran, metode, strategi pembelajaran, sumber belajar serta penilaian dari hasil wawancara yang mendalam dan studi dokumentasi yang dimulai pada tanggal 7 Januari 2020 diketahui bahwa penyusunan RPP yang dilakukan oleh guru-guru kelas II SD Muhammadiyah 4 Terpadu telah sesuai dengan acuan kurikulum 2013, guru telah diberi kebebasan untuk menuangkan kegiatan dalam proses pembelajaran yang di sesuaikan dengan kondisi dan karakteritik siswa. Berikut hasil wawancara dengan Ibu Norsidah, selaku guru kelas II SD Muhammadiyah 4 Terpadu : "Dalam penyusunan RPP, saya membuatnya menjadi satu untuk beberapa kali pertemuan tatap muka, hal ini dikarenakan adanya kesibukan yang harus diselesaikan." Beliau pun menambahkan, "RPP merupakan acuan dalam mengajar. Dalam pembuatan Rencana Pelaksanaan Pembelajaran (RPP) saya tidak mengalami hambatan karena sudah ada panduannya dan dibahas oleh guru-guru kelas II SD Muhammadiyah 4 Terpadu ini."

Ibu Lutfiatul Khoiroh selaku guru kelas II SD Muhammadiyah 4 Terpadu memaparkan sebagai berikut : "RPP merupakan langkah saya dalam mengajar dan menjadi panduan PBM. Secara umum dalam penyusunan RPP berbasis kurikulum 2013, saya tidak mengalami hambatan 
yang berarti, hal ini disebabkan telah adanya panduan dalam penyusunan RPP yang mengacu pada silabus."

c. Pelaksanaan Kegiatan Pembelajaran

Pembelajaran pada hakekatnya adalah proses interaksi antara siswa dengan lingkungannya sehingga terjadi perubahan perilaku ke arah yang lebih baik. Dalam interaksi tersebut banyak sekali faktor yang mempengaruhinya baik faktor internal maupun faktor eksternal yang datang dari lingkungan. Berdasarkan hasil wawancara dan observasi langsung yang dilakukan sendiri oleh peneliti, pelaksanaan pembelajaran meliputi tiga tahap, yaitu kegiatan awal/pendahuluan, kegiatan inti dan kegiatan akhir/penutupan. Penjelasan dari setiap tahapan adalah sebagai berikut

1). Kegiatan Awal (Pendahuluan)

Kegiatan pendahuluan pada dasarnya merupakan kegiatan awal yang harus ditempuh guru dan siswa pada setiap pelaksanaan pembelajaran. Fungsinya terutama untuk menciptakan suasana awal pembelajaran yang efektif yang memungkinkan siswa dapat mengikuti proses pembelajaran dengan baik. Guru kelas II di SD Muhammadiyah 4 Terpadu menggunakan waktu untuk kegiatan awal/pendahuluan dalam KBM kurang lebih 10 menit, dipergunakan untuk mengkondisikan ruang kelas sebelum menyajikan materi pelajaran. Strategi untuk mengkondisikan kelas yang digunakan oleh guru-guru kelas II SD Muhammadiyah 4 Terpadu berbeda-beda, ada yang mengawali dengan hafalan ayat Al-Quran yang terkait dengan materi, ada juga yang mengawali dengan tanya jawab tentang materi sebelumnya atau masalah-masalah yang lain yang berkaitan dengan materi yang akan dipelajari untuk mengetahui kesiapan dan kemampuan awal siswa sebelum materi baru diberikan.

Proses pembelajaran di awal waktu yang dilakukan guru-guru kelas II SD Muhammadiyah 4 Terpadu menurut hasil pengamatan peneliti adalah sebagai berikut : Ibu Norsidah, selaku guru kelas II-1: "Kegiatan ini diawali dengan salam, berdoa yang dipimpin oleh seorang siswa, guru mengecek atau memeriksa kehadiran siswa(presensi), lalu diadakan tadarus (membaca Juz Amma), baru kemudian guru menumbuhkan kesiapan belajar siswa (readness), menciptakan suasana belajar yang aktif, membangkitkan motivasi belajar siswa, dan membangkitkan perhatian siswa, menyampaikan tema dan tujuan pembelajaran serta menyampaikan teknik penilaian." Ibu Lutfiatul Khoiroh, selaku guru kelas II-4: "Di kegiatan awal pembelajaran guru mengucap salam, berdoa yang dipimpin oleh seorang siswa, hafalan Juz Amma kemudian guru mengecek kesiapan, kerapian pakaian dan posisi tempat duduk siswa, secara komunikatif memberikan pertanyaan kepada siswa berkaitan dengan materi di saat itu, lalu menyampaikan materi, tujuan pembelajaran dan kegiatan apa yang akan dilakukan serta teknik penilaian “

Ditambahkan lagi oleh Ibu Lutfiatul Khoiroh bahwa, "kebiasaan baik yang dilakukan guru terhadap muridnya seperti disiplin waktu, kebiasaan berdoa, hafalan Juz Amma, mengucap salam dalam setiap memulai pembelajaran, adalah sangat penting dan diperlukan demi tercapainya kualitas pembelajaran di kelas."
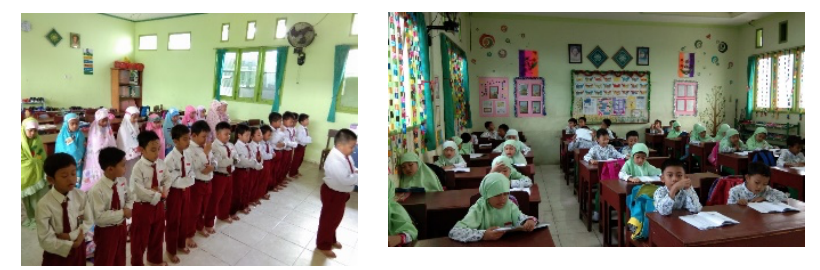

Kegiatan pagi hari seluruh siswa SD Muhammadiyah 4 Terpadu yaitu solat duha berjamaah di dalam kelas yang diimami salah seorang siswa. Kegiatan solat duha ini dilakukan setiap hari selasa sampai hari jum'at. Harapannya, ini akan menjadi pembiasaan sehari-hari agar melembaga pada diri anak sehingga dimanapun berada ibadah solat tetap dilaksanakan dengan baik. Kemudian dilanjutkan dengan hafalan surahsurah pendek Juz Amma dan kosakata tiga bahasa menggunakan buku panduan yang ditetapkan sekolah. Harapannya, kosakata ini akan menjadi modal kemudahan untuk memperlancar berbahasa setiap anak di kelas berikutnya.

Untuk mencapai pembelajaran yang berkualitas diperlukan perencanaan matang, jelas dan baik sehingga akan menghasilkan pencapaian tujuan pembelajaran yang optimal. Untuk itu kesiapan guru akan membuat proses pembelajaran menjadi runtut dan tertib, selain itu akan membuat anak mempunyai kepercayaan yang tinggi terhadap gurunya.

2). Kegiatan Inti Proses Pembelajaran

Kegiatan ini merupakan kegiatan dalam rangka pelaksanaan pembelajaran yang menekankan pada proses pembentukan pengalaman belajar siswa (Learning 
Experiences). Pengalaman belajar tersebut dapat dalam bentuk tatap muka dan non tatap muka. Pengalaman belajar tatap muka dimaksudkan sebagai kegiatan pembelajaran yang dilakukan dengan mengembangkan bentuk-bentuk interaksi langsung antara guru dengan siswa, sedangkan pengalaman belajar non tatap muka dimaksudkan sebagai kegiatan belajar siswa yang dilakukan siswa dalam berinteraksi dengan sumber belajar lain yang bukan kegiatan interaksi guru dan siswa.

Beberapa aspek yang diperhatikan peneliti pada saat wawancara maupun observasi PBM dikelas adalah metode atau strategi pembelajaran yang digunakan, metode pembelajaran termasuk penggunaan alat, media dan sumber belajar, penguasaan kelas dan gaya mengajar dari seorang guru. Dalam proses pembelajaran di kelas, guru kelas II SD Muhammadiyah 4 Terpadu menggunakan pendekatan saintifik dengan menerapkan langkah-langkah mengamati, menanya, mengumpulkan informasi, mengasosiasi, dan mengkomunikasikan, berkaitan dengan aspek materi meliputi keimanan, pengalaman, pembiasaan, rasional, dan keteladanan. Sesuai dengan pendekatanpendekatan pengajaran yang digunakan guru, metode-metode yang digunakannya pun bervariasi. Variasi metode-metode pembelajaran yang digunakan guru adalah metode ceramah di gunakan oleh guru untuk menyampaikan materi pokok, tanya jawab, demonstrasi dan lainnya. Hal ini berkaitan dengan materi yang diberikan adalah berkaitan dengan pemberian pesan dan nasehat. Siswa dalam proses pembelajaran di kurikulum 2013 lebih aktif namun tetap dalam arahan guru. Metode tanya jawab biasa digunakan kaitannya dengan pembahasan tentang pengalaman seharihari dan metode demonstrasi digunakan oleh guru pada waktu praktik membuat karya seni dari bahan alam, adapun pemberian tugas biasa diberikan diakhir materi pembelajaran dengan tujuan agar melakukan kegiatan belajar di rumah, metode ini diberikan karena dirasakan bahan pelajaran yang terlalu banyak sementara waktu kurang seimbang.

Alat, media dan sumber belajar yang digunakan guru dalam kegiatan belajar mengajar di SD Muhammadiyah 4 Terpadu sangatlah memadai sehingga memudahkan guru dalam melakukan proses pembelajaran yang efektif. Variasi gaya mengajar yang dilakukan guru pun berbeda-beda. Variasi ini meliputi variasi suara, variasi gerakan anggota badan, dan variasi perpindahan posisi guru dalam kelas. Setelah melalui proses observasi, peneliti dapat menuliskan : Ibu Norsidah, dalam menyampaikan materi pembelajaran terbiasa dengan suara berintonasi keras dan tegas. Materi yang disampaikan dengan jelas dan detail sehingga mudah dipahami. Untuk menfokuskan perhatian siswa pada aspek yang penting atau aspek kunci dalam pembelajaran, guru terlihat dengan mimik serius dan dikombinasikan dengan gerakan anggota badan sebagai bentuk penekanan. Proses pembelajaran dengan menggunakan media yang ada untuk memberikan informasi kepada siswa, dimana pada langkah pembelajaran ini siswa di tuntut untuk melakukan pengamatan pada tema pembelajaran, kemudian guru memberikan instruksi kepada siswa untuk berdiskusi, guru mengamati dan memberikan penilaian ketrampilan siswa.

Ibu Lutfiatul Khoiroh, terlihat tegas dan berwibawa namun beliau lebih banyak duduk dan berdiri di tempat dalam menyampaikan materi untuk menarik perhatian siswa, berinteraksi dengan siswa dengan mengarahkan pandangannya keseluruh kelas, dalam menyampaikan materi yang di selingi dengan mengajukan pertanyaan kepada siswa yang kurang memperhatikan, sesekali berdiri mengitari siswa di seluruh ruangan kelas dan memberikan arahan kepada siswa dalam menerapkan langkah-langkah pembelajaran dalam kurikulum 2013, memang tidak semua langkah dalam pendekatan saintifik diterapkan semua, namun pada dasarnya siswa lebih aktif.

Salah satu kegiatan inti pada muatan pembelajaran SBdP yang paling disukai anakanak adalah saat praktek membuat karya seni 3 dimensi yaitu membuat tempat alat tulis dari stik es krim.
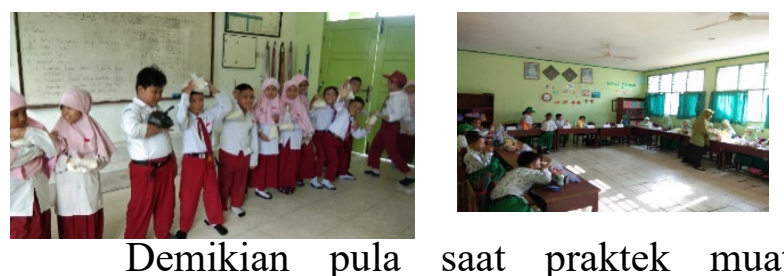
matematika untuk membawa beras dengan ketentuan berat yang berbeda-beda, yaitu 250 gram, 500 gram, dan 1 kilogram. Anak-anak terlihat antusias sekali, bahkan ingin lebih dahulu untuk praktek maju di depan kelas. Guru membagi siswa, yaitu menyamakan berat timbangan beras yang dibawa, kelompok I terdiri dari 2 anak yang 
membawa 1 kilogram beras, dan kelompok II diarahkan untuk anak yang membawa 250 gram beras. Anak-anak diminta agar berat beras sama, maka berapa orang lagi yang harus ditambahkan pada kelompok II. Harapannya, anak-anak makin paham tentang pengukuran berat benda dan dapat menerapkan dalam kegiatan sehari-hari.

Salah satu kegiatan lain pada muatan pelajaran matematika dan PKn adalah jual beli (berniaga), yaitu praktek berjualan dengan harga yang telah ditentukan guru dan etika saat berniaga.
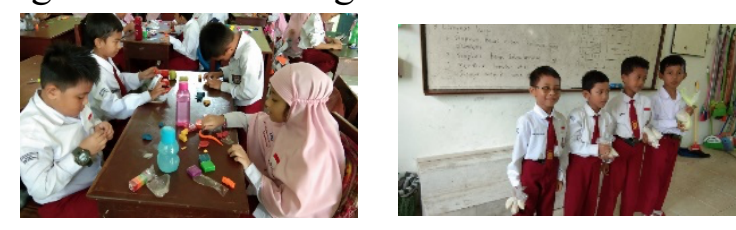

Kegiatan lain muatan pelajaran SBdP adalah membuat prakarya 3 dimensi menggunakan plastisin, yaitu bahan lunak berwarna-warni yang mudah dibentuk menjadi benda atau mainan. Anak-anak duduk berkelompok yang terdiri dari 3-4 anak, hal ini dilakukan guru agar anak-anak dapat saling membantu apabila ada teman yang merasa kesulitan membuat prakaryanya.

Pembelajaran muatan pelajaran bahasa indonesia dimulai dengan guru mengajak siswa untuk membaca cerita pada buku paket. Dilanjutkan dengan tanya jawab singkat tentang isi cerita yang telah dibaca.

3). Kegiatan Akhir Pembelajaran

Belajar dapat dikatakan suatu proses yang tidak pernah berhenti karena merupakan suatu proses yang berkelanjutan menuju ke arah kesempurnaan. Setiap kali berakhir dari suatu interaksi antara guru dengan siswa, hanyalah merupakan suatu terminal saja untuk kemudian beranjak ke interaksi selanjutnya pada hari atau minggu yang lain.

Pada akhir pembelajaran, guru memberikan kesempatan beberapa orang ke depan kelas untuk mengulang materi secara singkat, sedangkan anak-anak yang lain akan menyimak dengan seksama. Disini guru menjadi pendengar saja dan akan mengarahkan bila ada hal yang kurang dipahami anak-anak. Pada kesempatan ini, guru melakukan penilaian pada beberapa anak yang berani dan bisa menjelaskan materi dengan lancar.

Berdasarkan hasil pengamatan yang peneliti lakukan kepada guru-guru kelas II dalam mengakhiri proses pembelajaran dapat dipaparkan
: Ibu Norsidah, di kegiatan akhir digunakan untuk bertanya kepada beberapa siswa terkait dengan materi, memberikan pesan dengan nada yang tegas terkait dengan materi, kemudian memberikan tugas individu yang diberikan kepada siswa untuk dikumpulkan esok hari, dan menutup pembelajaran dengan salam. Menurut Ibu Lutfiatul Khoiroh, kegiatan akhir dalam pembelajaran tidak hanya diartikan kegiatan untuk menutup pelajaran, tetapi juga dimanfaatkan untuk mengulas pokok-pokok materi yang telah diajarkan, tanya jawab tentang pelajaran yang belum dipahami siswa, pemberian tugas rumah (PR) untuk diselesaikan dan dikumpulkan pada pertemuan berikutnya, bahkan kadang digunakan juga untuk kegiatan penilaian hasil belajar siswa, mengemukakan topik yang akan dibahas pada waktu yang akan datang, kemudian dilanjutkan dengan menutup kegiatan pembelajaran.

c. Evaluasi Pembelajaran

Evaluasi pembelajaran dalam implementasi/pelaksanaan kurikulum 2013 dapat menggunakan sistem penilaian autentik. Alat penilaian yang digunakan dalam penilaian autentik diantaranya : a) tes tertulis maupun lisan, b) tugas individu maupun tugas kelompok, c) portofolio. Berdasarkan hasil observasi dan wawancara, evaluasi yang dilakukan oleh para guru kelas II SD Muhammadiyah 4 Terpadu sudah melaksanakan penilaian autentik yaitu dari proses awal sampai akhir pembelajaran yang mencakup empat (4) kompetensi inti yang ada dalam kurikulum 2013 yaitu kompetensi dari aspek spiritual, aspek sosial, aspek pengetahuan dan aspek ketrampilan. Penilaian aspek pengetahuan (kognitif) dilakukan setelah siswa mempelajari satu kompetensi dasar yang harus dicapai, sedangkan aspek afektif yang meliputi spiritual dan sosial dilakukan selama berlangsungnya kegiatan belajar mengajar, baik di dalam maupun diluar kelas, yang berorientasi pada perilaku siswa sehari-hari yang dinilai seperti kedisiplinan, sopan santun siswa pada guru, karyawan dan teman sekolah. Untuk aspek ketrampilan dilakukan selama berlangsungnya proses pembelajaran yang berorientasi pada ketrampilan motorik.

Ada beberapa jenis alat penilaian yang digunakan oleh para guru kelas II SD Muhammadiyah 4 Terpadu, yaitu: a) pertanyaan lisan di kelas, dalam penilaian ini guru memberi pertanyaan kepada siswa. Semua siswa diberi kebebasan untuk menjawab pertanyaan yang 
diajukan guru, benar atau salah yang didapat dari siswa selanjutnya dilempar lagi kepada siswa untuk mendapat klarifikasi jawaban yang pertama. Setelah itu dapat menyimpulkan tentang jawaban siswa yang benar; b) Penilaian harian, yaitu terdiri dari seperangkat soal yang harus dijawab para siswa. Guru membuat soal dalam bentuk pilihan ganda dan jawaban singkat. Penilaian harian ini dilakukan minimal 4 kali untuk setiap muatan pelajaran dan setiap tema dalam setiap semester.; c) Tugas Individu, yaitu tugas yang di berikan guru sering terkait dengan ranah kognitif dan psikomotorik. Tugas individu yang dilakukan oleh guru kelas II SD Muhammadiyah diantaranya adalah memberikan soal latihan yang dikerjakan di rumah(muatan matematika), menulis ulang teks bacaan menggunakan huruf tegak bersambung(muatan bahasa Indonesia), menuliskan sikap pengalaman sila kedua pancasila yang dilakukan di rumah(muatan PPKn), menyiapkan bahan kerajinan untuk prakarya yang akan dilaksanakan beberapa hari kemudian(muatan SBdP) ; d) Penilaian Semester, dilakukan pada akhir semester secara bersama untuk semua kelas.

Adapun bahan yang diujikan dalam penilaian semester sebagai berikut : (a) Penilaian semester pertama, soalnya diambil dari materi semester pertama; (b) Penilaian semester kedua, soalnya merupakan gabungan dari semester pertama dan semester kedua dengan penekanan pada semester kedua. Penilaian semester ini biasa dilakukan oleh guru untuk mengetahui kemajuan dan hasil siswa, mendiagnosa kesulitan belajar, memberi umpan balik perbaikan proses pembelajaran dan penentuan kenaikan kelas; e) Penilaian Sikap, penilaian sikap diberikan para guru kelas II SD Muhammadiyah 4 Terpadu dengan cara observasi perilaku, baik sikap terhadap materi pelajaran, sikap terhadap guru/pengajar, sikap terhadap proses pembelajaran maupun sikap yang berkaitan dengan nilai, norma atau akhlak; f) Portofolio, kumpulan dan hasil karya siswa termasuk penilaian harian dan tugas lainnya; h) Penilaian diri.

\section{PEMBAHASAN}

Implementasi Kurikulum 2013 dalam Pembelajaran Tematik di SD Muhammadiyah 4 Terpadu.
Keberhasilan

pengimplementasian kurikulum memerlukan manajemen yang baik. Dalam rangka mengimplementasikan kurikulum 2013, ada beberapa aspek manajemen yang penting sebagai strategi untuk memperkuat pelaksanaannya. Aspek-aspek tersebut meliputi perencanaan implementasi, sumber daya utama dan pendukung, proses pembelajaran di sekolah, dan kegiatan monitoring dan evaluasi. Komponen sekolah terdiri atas guru, kepala sekolah, fasilitas, budaya, lingkungan. Semua komponen tersebut memiliki peran masing-masing dalam penerapan kurikulum baru. Dengan demikian, semua potensi dan sumber daya yang ada perlu dikelola secara menyeluruh dan terpadu agar implementasi berjalan dengan hasil yang optimal.

Kurikulum 2013 dikembangkan sesuai dengan potensi sekolah atau daerah, karakteritik sekolah dan karakteristik para siswa. Selain itu, dalam pengembangan Kurikulum 2013 harus memperhatikan Standar Isi (SI) dan Standar Kompetensi Lulusan (SKL) yang sudah ditetapkan melalui Peraturan Menteri Pendidikan Nasional (Permendiknas, 2013). Dalam kurikulum 2013, guru merupakan the key person dalam keberhasilan pembelajaran. Guru adalah orang yang diberi tanggung jawab untuk mengembangkan dan melaksanakan kurikulum hingga mengevaluasi ketercapaiannya. Guru adalah figur yang sangat berperan dalam proses dan hasil belajar siswa. Karakter guru perlu dibangun sesuai dengan kebutuhan dan perkembangan zaman.

Pelaksanaan kurikulum memerlukan petunjuk atau pedoman, pedoman itu memberikan gambaran tentang garis-garis besar pengajaran (GBPP), pengertian adalah tentang pokok bahasan, alokasi waktu, pendekatan yang digunakan, metode penyampian, media pengajaran, sumber pokok materi dan penilaian. Dalam implementasi kurikulum 2013 di SD Muhammadiyah 4 Terpadu, guru-guru kelas II menghadapi proses belajar mengajar melakukan tahapan-tahapan yang akan di lalui, tahapan tersebut antara lain :

a. Persiapan Pelaksanaan Pembelajaran

1) Pengembangan Program

Pada kurikulum 2013 guru diberi kewenangan penuh untuk menyusun dan mengembangkan program. Pengembangan program tersebut mencakup antara lain : Pertama, program tahunan. Program ini dipersiapkan dan 
dikembangkan oleh guru sebelum tahun ajaran, karena merupakan pedoman bagi pengembangan program-program berikutnya, yaitu program semester, program mingguan, dan program harian atau program pembelajaran setiap kompetensi dasar. Kedua, program semester. Program ini berisikan garis-garis besar mengenai hal-hal yang hendak dilaksanakan dan akan dicapai dalam semester tersebut. Program semester ini merupakan penjabaran dari program tahunan. Ketiga, program mingguan dan harian, Program ini merupakan penjabaran dari program semester. Melalui program ini dapat diketahui tujuan-tujuan yang telah dicapai dan yang perlu diulang bagi setiap siswa.

Keempat, program pengayaan dan remedial. Program ini merupakan pelengkap dan penjabaran dari program mingguan dan harian. Dari program ini teridentifikasi siswa-siswa yang mengalami kesulitan belajar akan dilayani dengan kegiatan remedial, sedangkan untuk siswa yang cemerlang akan dilayani dengan kegiatan pengayaan agar tetap mempertahankan kecepatan belajarnya. Kelima, program pengembangan diri. Program pengembangan diri sebagian besar diberikan melalui kegiatan ekstrakurikuler maupun melalui bimbingan dan konseling atau konselor kepada para siswa yang menyangkut pribadi, sosial, belajar, dan karier.

Adapun pengembangan program tahunan, program semester, program mingguan dan harian yang disusun oleh guru-guru kelas II di SD Muhammadiyah 4 Terpadu telah disusun sesuai dengan acuan dalam Kurikulum 2013. Para guru menyusun program mingguan dan harian secara bersama-sama dalam satu tim. Biasanya program tersebut disusun pada awal tahun pelajaran. Setiap guru mempunyai tugas masing-masing, sehingga dalam penyusunannya tidak mengalami hambatan yang berarti. Menurut Muslich (2007:44) hal-hal yang seharusnya dilakukan guru dalam penyusunan Program Tahunan (Prota) dan Program Semester (Promes) adalah sebagai berikut (1) Mendaftar kompetensi dasar pada setiap unit berdasarkan hasil pemetaan kompetensi dasar per unit yang telah disusun, (2) Mengisi jumlah jam pelajaran setiap unit berdasarkan hasil analisis alokasi waktu yang telah disusun, (3) Menentukan materi pembelajaran pokok pada setiap kompetensi dasar yang didapatkan dari pengembangan silabus, (4) Membagi habis jumlah jam pelajaran setiap unit berdasarkan hasil analisis alokasi waktu yang telah disusun.

Pelaksanaan program pengayaan dan remedial oleh guru-guru kelas II SD Muhammadiyah 4 Terpadu sudah sesuai dalam konsep Kurikulum 2013 yaitu berdasarkan teori belajar tuntas. Seorang siswa dipandang tuntas belajar jika ia mampu menyelesaikan, menguasai kompetensi atau mencapai tujuan pembelajaran minimal $75 \%$ dari seluruh tujuan pembelajaran. SD Muhammadiyah 4 Terpadu memiliki Kriteria Ketuntasan Minimum (KKM) yang harus dicapai adalah 75 untuk penguasaan konsep dan penerapan konsep. Dalam konsep Kurikulum 2013 sekolah berkewajiban memberikan program pengembangan diri melalui bimbingan dan konseling kepada siswa yang menyangkut keimanan, pribadi, sosial, belajar dan ketakwaan. Konsep ini sudah diterapkan di SD Muhammadiyah 4 Terpadu, di sekolah ini pengembangan diri sebagian besar melalui kegiatan ekstrakurikuler dan bimbingan konseling melalui konselor.

2) Penyusunan Persiapan Mengajar

Dalam prinsip pengembangan silabus berbasis kurikulum 2013, setiap satuan pendidikan diberi kebebasan dan keleluasaan dalam mengembangkan RPP sesuai dengan kondisi dan kebutuhan masing-masing sekolah. Prinsip ini telah dilaksanakan oleh guru-guru SD Muhammadiyah 4 Terpadu dalam mengembangkan silabus tersebut. Dalam mengembangkan silabus ke dalam Rencana Pelaksanaan Pembelajaran yang sesuai dengan acuan kurikulum 2013 perlu diperhatikan langkah-langkah sebagai berikut : (1) mengkaji Kompetensi Inti (KI) dan Kompetensi Dasar (KD), (2) mengidentifikasi materi pokok, (3) mengembangkan pengalaman belajar, (4) merumuskan indikator keberhasilan belajar, (5) penentuan jenis penilaian, (6) menentukan alokasi waktu. Secara umum dalam pengembangan silabus, guru kelas II tidak mengalami hambatan yang berarti, karena guru-guru tersebut dalam penyusunan silabus dilaksanakan secara bersamasama dalam sebuah tim yaitu dalam Kelompok Kerja Guru(KKG) tingkat sekolah. Begitu juga dalam penyusunan Rencana Pelaksanaan Pembelajaran (RPP) yang sesuai dengan acuan Kurikulum 2013. Secara umum guru tidak mengalami kesulitan dalam menyusun RPP tersebut, karena guru sudah mendapat acuan atau 
pedoman dalam penyusunan RPP tersebut. Dalam penyusunan RPP guru diberi kebebasan untuk dalam mengembangkan silabus yang disesuaikan dengan kondisi sekolah, media, serta karakteristik siswa.

\section{b. Pelaksanaan Kegiatan Pembelajaran}

Secara konseptual, draft Kurikulum 2013 dicita-citakan untuk mampu melahirkan generasi masa depan yang cerdas intelektualnya, tetapi juga cerdas emosi, sosial, dan spiritualnya. Hal itu tampak dengan terintegrasikannya nilai-nilai karakter ke dalam proses pembelajaran. Pendekatan dan strategi pembelajaran yang di gunakan dengan memberikan ruang kepada siswa untuk mengontruksi pengetahuan baru berdasarkan pengalaman belajar yang diperoleh dari kelas, lingkungan sekolah, dan masyarakat juga akan mampu mendekatkan siswa kepada kultur masyarakat dan bangsanya. Kurikulum 2013 menjadi salah satu solusi menghadapi perubahan zaman yang kelak akan mengutamakan kompetensi yang di sinergikan dengan nilai-nilai karakter. Guru dalam berinovasi untuk melakukan pembaharuan pada pembelajaran membutuhkan kreativitas, sehingga pembelajaran yang dilakukannya benar-benar bersifat menantang siswa, karena siswa disuguhi dengan hal yang mungkin belum ditemukan oleh siswa. Indikator kreativitas dan inovasi seorang guru dapat dilihat dari prestasi siswanya mencapai taraf tertentu sesuai standar yang telah ditentukan. Inovasi dan kreativitas yang dimiliki seorang guru akan menjadi instrumen pendorong suatu pekerjaan profesional dapat dilakukan secara optimal serta mampu mengembangkan kompetensi siswa secara optimal melalui proses pembelajaran yang dilakukannya. Guru sebagai ujung tombak pelaksana kurikulum menjadi aktor pertama dan utama sukses tidaknya sebuah kurikulum diimplementasikan pada dataran sekolah atau kelas.

Untuk mencapai tujuan pembelajaran Tematik, sebaiknya proses pembelajaran tidak hanya menggunakan strategi belajar yang terpaku pada guru, atau dengan metode yang monoton, guru perlu memahami strategi dan pendekatan yang sesuai dengan kurikulum 2013

1) Penggunaan Metode atau Strategi Pembelajaran

Pemilihan dan penggunaan strategi atau metode pembelajaran di SD Muhammadiyah 4 Terpadu sudah mengarah pada pemilihan strategi atau metode pembelajaran yang dianjurkan dalam
Kurikulum 2013. Dalam konsep Kurikulum 2013, guru harus mampu menciptakan kondisi kelas yang menyenangkan, dan kontekstual. Untuk menciptakan kondisi kelas yang menyenangkan, dan kontekstual, guru telah mengurangi metode ceramah dalam pembelajaran. Guru kelas II di SD Muhammadiyah 4 Terpadu dalam pembelajaran telah menerapkan metode ceramah bervariasi, tanya jawab, observasi serta penugasan. Pemilihan metode pembelajaran disesuaikan dengan kompetensi atau materi(tema) yang harus dikuasai siswa dan waktu yang tersedia. Dalam proses pembelajaran Tematik dengan menggunakan Kurikulum 2013 di SD Muhammadiyah 4 Terpadu, keaktifan siswa sangat diprioritaskan.

2) Penggunaan Sumber Belajar

Dalam pembelajaran Tematik di SD Muhammadiyah 4 Terpadu telah menggunakan sumber pembelajaran yang variatif untuk menunjang pemahaman siswa terhadap materi pelajaran. Sumber belajar tersebut antara lain buku paket dan latihan soal yang diberikan guru. Agar penggunaan sumber belajar dapat optimal, maka hendaknya memperhatikan hal-hal berikut : (1) sumber belajar atau media pembelajaran yang dipilih dapat dipakai untuk mencapai tujuan atau kompetensi yang ingin dicapai, (2) sumber belajar atau media pembelajaran yang dipilih dapat memudahkan pemahaman siswa, (3) sumber belajar atau media pembelajaran dideskripsikan secara spesifik dan sesuai dengan materi pembelajaran, (4) sumber belajar atau media pembelajaran yang dipilih sesuai dengan tingkat perkembangan kognitif, karakteristik afektif, dan ketrampilan motorik siswa.

3) Penggunaan Media Pembelajaran

Pelaksanaan belajar mengajar Tematik di SD Muhammadiyah 4 Terpadu, guru kelas II telah berusaha menggunakan media pembelajaran yang variatif untuk menciptakan lingkungan belajar yang kondusif dan menyenangkan. Dengan sarana/prasarana yang lengkap dapat menunjang penerapan Kurikulum 2013.

4) Evaluasi Hasil Belajar

Penilaian dalam Kurikulum 2013 menggunakan prinsip penilaian autentik dan komprehensip guna mendukung upaya memandirikan siswa untuk belajar, bekerja sama, dan menilai diri senidiri. Penilaian hasil belajar dalam kurikulum 2013 dapat dilakukan dengan tes kemampuan dasar baik yang kognitif, afektif maupun ketrampilan. Adapun penilaian yang 


\section{Nani Astutiningsih. Jurnal Pendas Mahakam. Vol 5 (2). 140-155 Desember 2020}

dilakukan oleh guru kelas II di SD Muhammadiyah 4 Terpadu sudah mengikuti penilaian yang disyaratkan dalam kurikulum 2013. Pendekatan penilaian dengan menggunakan penilaian diri sendiri, tes kemampuan dasar, portofolio, tugas mandiri maupun tugas kelompok.

Menurut Badan Standar Nasional Pendidikan ( BSNP ) pelaksanaan penilaian hasil belajar siswa didasarkan pada prinsip-prinsip sebagai berikut :

(1) Mendidik, yaitu mampu memberikan sumbangan positif terhadap peningkatan pencapaian belajar siswa.

(2) Terbuka/transparan, yaitu prosedur penilaian, kriteria penilaian, dan dasar pengambilan keputusan diketahui pihak yang terkait.

(3) Menyuluruh, yaitu meliputi berbagai aspek kompetensi yang akan dinilai yaitu meliputi ranah pengetahuan (kognitif), ketrampilan (psikomotor), sikap dan nilai (afektif) yang direfleksikan dalam kebiasaan berfikir dan bertindak.

(4) Terpadu dengan pembelajaran, yaitu menilai apapun yang dikerjakan siswa dalam kegiatan belajar mengajar itu dinilai, baik kognitif, psikomotorik dan afektifnya.

(5) Objektif, yaitu tidak terpengaruh oleh pertimbangan subjektif penilai.

(6) Sistematis, yaitu penilaian dilakukan secara berencana dan bertahap untuk memperoleh gambaran tentang perkembangan belajar siswa sebagai hasil kegiatan belajarnya.

(7) Berkesinambungan, yaitu dilakukan secara terus menerus sepanjang berlangsungnya kegiatan pembelajaran.

(8) Adil, yaitu tidak ada siswa yang diuntungkan atau dirugikan berdasarkan latar belakang sosial ekonomi, budaya, agama, bahasa, suku, bangsa, warna kulit dan jender.

(9) Menggunakan acuan kriteria, yaitu menggunakan kriteria tertentu dalam menentukan kelulusan siswa.

Model penilaian yang diterapkan guru kelas II di SD Muhammadiyah 4 Terpadu meliputi dua model yaitu non tes dan tes. Model non tes meliputi observasi/pengamatan terhadap sikap siswa dalam proses pembelajaran, sedangkan model tes meliputi tes lisan dan tes tertulis (tes tertulis uraian dan objektif). Evaluasi hasil belajar pada Kurikulum 2013 di SD Muhammadiyah 4 Terpadu menyangkut tiga ranah yaitu ranah kognitif (pemahaman konsep), ranah afektif (penerapan konsep), dan ranah ketrampilan. Di SD Muhammadiyah 4 Terpadu telah ditentukan Kriteria Ketuntasan Minimum (KKM) sebesar 75 untuk penguasaan konsep dan ketrampilan, sedangkan dalam ranah afektif dengan menggunakan skor maksimal 4 point.

Pada SD Muhammadiyah 4 Terpadu telah diterapkan sistem belajar tuntas yaitu seorang siswa dianggap tuntas belajar jika siswa tersebut mampu menyelesaikan, menguasai kompetensi atau mencapai tujuan pembelajaran yaitu mampu memperoleh nilai 75 . Siswa yang belum mencapai nilai tersebut dikatakan belum tuntas belajarnya, yaitu guru memberikan perlakuan khusus terhadap siswa yang masih mendapat kesulitan belajar melalui remedial, sedangkan bagi siswa yang cemerlang dan telah tuntas belajarnya diberikan kesempatan untuk tetap mempertahankan kecepatan belajarnya melalui program pengayaan.

Wawancara dengan Bapak Zaenal Arifin, Wakil Kepala Sekolah SD Muhammadiyah 4 Terpadu Samarinda, mengungkapkan bahwa pada dasarnya Kurikulum 2013 merupakan penyempurnaan KTSP, pada Kurikulum 2013 mengikat materi dari masing-masing tema, dan harapannya anak-anak mampu memahami secara holistik disetiap muatan pembelajaran tematik. Bahan ajar pada Kurikulum 2013 dari berbagai sumber, yaitu buku pemerintah yang dikembangkan dengan bahan ajar lain, yaitu penerbit Airlangga, Tiga Serangkai, Yudistira dan yang lainnya. Wawancara dengan Bapak Jaswadi, Kepala Sekolah SD Muhammadiyah 4 Terpadu Samarinda, mengungkapkan bahwa Kurikulum 2013 adalah program pendidikan yang dinamis tidak stagnan, sehingga Kurikulum menyesuaikan perkembangan zaman. Pada tahun 2006 menggunakan KTSP dan sekarang disempurnakan menjadi Kurikulum 2013, dan ini pasti akan disempurnakan lagi. Implementasi Kurikulum 2013 di SD Muhammadiyah 4 Terpadu Samarinda beberapa tahun ini banyak mengalami revisi-revisi dan saat ini sudah dalam tahap penyempurnaan,

Berdasarkan wawancara Kepala Sekolah dan Wakil Kepala Sekolah, terlihat adanya persamaan pendapat, yaitu kurikulum pendidikan selalu mengalami perubahan menyesuaikan segala kebutuhan perkembangan zaman untuk memenuhi kebutuhan kehidupan yang semakin kompleks. Perubahan Kurikulum 2006 ditambah pendidikan 


\section{Nani Astutiningsih. Jurnal Pendas Mahakam. Vol 5 (2). 140-155 Desember 2020}

karakter menjadi Kurikulum 2013 semakin sempurna mengikuti kebutuhan kehidupan.

\section{KESIMPULAN}

Setelah dilakukan analisa data tentang implementasi Kurikulum 2013 di SD Muhammadiyah 4 Terpadu Samarinda, dapat ditarik kesimpulan sebagai berikut :

1) Aspek-aspek Implementasi Kurikulum 2013 meliputi perencanaan implementasi Kurikulum 2013, sumber daya utama dan pendukung, proses pembelajaran di sekolah, dan kegiatan monitoring dan evaluasi. Komponen sekolah terdiri atas guru, kepala sekolah, fasilitas, budaya, dan lingkungan memiliki peran masing-masing dalam penerapan Kurikulum 2013. Guru Kelas II menghadapi proses belajar mengajar melalui tahapan persiapan pelaksanaan pembelajaran dan pelaksanaan kegiatan pembelajaran.

2) Evaluasi pelaksanaan Kurikulum 2013 di SD Muhammadiyah Samarinda perlu diawali dengan pemenuhan Standar Nasional Pendidikan. Untuk itu dalam rangka pengimplementasian Kurikulum 2013 di seluruh sekolah pemerintah perlu terus mendorong terwujudnya pemenuhan Standar Nasional. Selain itu para pengelola sekolah piloting Kurikulum 2013 maupun sekolah pelaksana mandiri (kepala sekolah, pengawas, dan dinas pendidikan) perlu menjaga situasi dan kondisi agar motivasi guru dalam menjalankan tugas profesi tetap tinggi sehingga memiliki kinerja yang baik.

3) Hambatan-hambatan yang menjadi kendala guru kelas II SD Muhammadiyah 4 Terpadu Samarinda pada pelaksanaan Kurikulum 2013 adalah pada penilaian autentik yang terdiri dari 4 aspek yaitu aspek sosial, aspek spiritual, aspek pengetahuan dan aspek keterampilan, yang mengharuskan seorang guru harus mengidentifikasi seluruh siswa yang mempunyai karakteristik yang berbedabeda. Selain itu, kurangnya motivasi orang tua siswa kepada anaknya agar rajin belajar dan kurang siapnya siswa sendiri dalam menerima Kurikulum baru tersebut, karena sebelumnya anak terbiasa dengan proses pembelajaran yang konvensional yang hanya duduk, diam, mendengarkan penyampaian materi dari guru.
4) Solusi dalam menghadapi hambatan dalam Implementasi Kurikulum 2013 yaitu (1) mengikutkan guru-guru dalam workshopworkshop tentang Kurikulum 2013, (2) melengkapi sarana/prasaran yang menunjang terlaksananya kurikulum 2013, mengadakan evaluasi setiap 1 semester, (4) membentuk tim khusus pengembang Kurikulum 2013, (5) rutin melakukan supervisi guru, (6) membuat aplikasi penilaian untuk memudahkan guru dalam meng-input data nilai, (7) penyempurnaan jadwal tenaga pengajar.

\section{DAFTAR PUSTAKA}

Albantani, A. M. (2015). Implementasi Kurikulum 2013 Pada Pembelajaran Bahasa Arab Di Madrasah Ibtidaiyah. Arabiyat: Jurnal Pendidikan Bahasa Arab Dan Kebahasaaraban, 2(2), 178-191. https://doi.org/10.15408/a.v2i2.2127 diakses pada tanggal 2 November 2019

Ahmad Yani, DR, (2007). Mindsed Kurikulum, Jakarta: Grafindo Media Pratama.

Danu Prabowo, "Perbedaan Kurikulum 2013 dan KTSP", diakses dari https://www.kompasiana.com/danuprbwo/54f5f be2a333116a7d8b4742/yang-menjadikanperbedaan-kurikulum-2013-dan-ktsp\#, diakses pada tanggal 9 November 2019 pukul 21.00 Danmole, B.T. (2011). Emerging on the Universal Basic Education Curriculum in Nigeria:Implications for the science and Technology Component. Pakistan Journal of Social Science 8(1), 62-68.

Djemari Mardapi (2004) Pengembangan Sistem Penilaian Berbasis Kompetensi, Seminar Nasional Rekayasa Sistem Penilaian Dalam Rangka Meningkatkan Kualitas Pendidikan. HAPY Yogyakarta, 26 s/d 27 maret 2004.

Fitriadi, A. (2016). The Correlation between Critical Thinking Skills and Critical Thinking Dispositions of the Fifth Semester Student of English Department in Academic Years 2015/2016. Konferensi Antarabangsa Islam Borneo Ke-9 (KAIB IX), 9(25), 250.

Goleman, daniel; boyatzis, Richard; Mckee, A. (2019). Journal of Chemical Information and Modeling, 53(9), 1689-1699. https://doi.org/10.1017/CBO9781107415324. 004, diakses 12 November 2019 
Hilda, K. Penerapan Pembelajaran Tematik SD di Indonesia. Diakses tanggal 5 Desember 2019

dari

https://www.google.com/search?safe=strict \&sxsrf=ACYBGNRoEcMo9nQ3NqmFpTe DTnBT3z8nog\%3A1575538975446\&ei=H 9HoXbvqGonXz7sPrfyzwAE\&q=artikel $+\mathrm{k}$ arli\%2C+hilda $+2012 \&$ oq $=$ artikel + karli $\% 2$ $\mathrm{C}+$ hilda $+2012 \& \mathrm{gs} 1=$ psyab.12...94354.103993..113829...0.0..0.255. $2573.23 \mathrm{j} 3 \mathrm{j} 1 \ldots \ldots . . \ldots 1 . . . \mathrm{gws}-$ wiz.......35i39j35i304i39j0i8i30j0i8i7i30j0i 7i30j0i7i10i30.wls5hjHy2LU\&ved=0ahUK Ewj79deHnJ7mAhWJ63MBHS3DBgQ4dUDCAo

Hosnan, M. (2014). Pendekatan Saintifik dan Kontekstual dalam Pembelajaran Abad 21 Kunci Sukses Implementasi Kurikulum 2013, Jakarta: Ghalia Indonesia.

Indah Lestari, Pengembangan Model Bimbingan Kelompok dengan teknik Simulasi untuk Meningkatkan Kecerdasan Emosi Siswa, Journal Bimbingan konseling, (Semarang:2012), hlm. 67. Diakses tanggal 8 Desember 2019

https://www.google.com/search?q=artikel+ indah+lestari $+2012 \&$ oq $=$ artikel + indah + lest ari $+2012 \&$ aqs $=$ chrome. $.69 i 57.12122 j 0 j 7 \& s$ ourceid $=$ chrome \&ie $=$ UTF-8

Indriani, F. (2015), Kompetensi Pedagogik Mahasiswa Dalam Mengelola Pembelajaran Tematik Integratif Kurikulum 2013 Pada Pengajaran Mikro di PGSD UAD Yogyakarta. Junal Profesi Pendidikan Dasar, 2(2), 87-94. Diakses tanggal 10 Desember 2019

Kementerian Pendidikan Dan Kebudayaan. (2016). Dokumen kurikulum 2013, Kementerian Pendidikan Dan Kebudayaan, (Desember), 1-23.

Krissandi, A. D. S., \& Rusmawan, R. (2015). Kendala Guru Sekolah Dasar Dalam Implementasi Kurikulum 2013. Jurnal
Cakrawala Pendidikan, 3(3), 457-467. https://doi.org/10.21831/cp.v3i3.7409, diakses tanggal 11 Desember 2019

Octaviani, S. (2017). Pengembangan Bahan Ajar Tematik Dalam Implementasi Kurikulum 2013 Kelas 1 Sekolah Dasar. EduHumaniora | Jurnal Pendidikan Dasar Kampus Cibiru, 9(2), 93. https://doi.org/10.17509/eh.v9i2.7039

Orodho, J. A., Waweru, P. N., Ndichu, M., \& Nthinguri, R. (2013). Basic Education in Kenya: Focus on Strategies applied to cope with school-based challenges inhibiting effective implementation of curriculum. International Journal of Education and Research, 1(11), 1-20.

Goodman, F. S. (1918). Religious education in camps. Religious Education, 13(6), 417 420.

https://doi.org/10.1080/0034408180130607

Rini Kristiantari, M. (2015). Analisis Kesiapan Guru Sekolah Dasar dalam Mengimplementasikan Pembelajaran Tematik Integratif Menyongsong Kurikulum 2013. JPI (Jurnal Pendidikan Indonesia), 3(2), 460-470. https://doi.org/10.23887/jpiundiksha.v3i2.4462

Resbiantoro, G. (2016). Analisis Pedagogical Content Knowledge (Pck) Terhadap Buku Guru Sd Kurikulum 2013. Scholaria: Jurnal Pendidikan Dan Kebudayaan, 6(3), 153.

https://doi.org/10.24246/j.scholaria.2016.v6 i3.p153-162

Sinambela, P. N. J. M. (2013). Kurikulum 2013 , Guru , Siswa , Afektif , Psikomotorik , Kognitif. E-Journal Universitas Negeri Medan, 6, 17-29.

Studi, P., Ilmu, P., Sosial, P., \& Yogyakarta, U. P. (2016). Enam Sekolah Sasaran Sma Di Kabupaten Bantul Daerah Istimewa Yogyakarta Tesis Halaman Persetujuan Efektifitas Implementasi Kurikulum 2013 Pada Bantul Daerah Istimewa Yogyakarta. 